\title{
Substitution of Soybean Meal with Indigofera zollingeriana Top Leaf Meal on Egg Quality of Cortunix cortunix japonica
}

\author{
F. Faradillah ${ }^{\mathrm{a}}$, R. Mutia ${ }^{\mathrm{b}, *}$, \& L. Abdullah ${ }^{\mathrm{b}}$ \\ aStudy Program of Nutrition and Feed Science, Faculty of Animal Science, Graduate School, \\ Bogor Agricultural University \\ ${ }^{b}$ Department of Nutrition and Feed Technology, Faculty of Animal Science Bogor Agricultural University \\ Kampus IPB Darmaga, Bogor 16680, Indonesia \\ (Received 06-08-2015; Reviewed 07-09-2015; Accepted 16-10-2015)
}

\begin{abstract}
This research aimed to study the substitution of soybean meal (SBM) with Indigofera zollingeriana top leaf meal (ILM) in the diet on egg quality of Japanese quails. The experiment used a completely randomized design with five treatments and four replications (ten quails of each replication). The dietary treatment contained five combination of SBM and ILM, R0= diets contained $18 \%$ SBM without ILM, R1= diet contained 16.2\% SBM and 2.66\% ILM, R2= diet contained 14.4\% SBM and $5.32 \%$ ILM, R3= diet contained $\mathbf{1 2 . 6 \%}$ SBM and 7.98\% ILM, R4= diet contained 9\% SBM and $13.3 \%$ ILM. The results showed that the use of $13.3 \%$ ILM $(R 4)$ significantly $(P<0.05)$ increased feed consumption, egg weight, yolk colour score, egg cholesterol, and reduced malondialdehyde level. The conclusion of this study was $I$. zollingeriana top leaf meal could be used as much as $13.3 \%$ in the diets. The use of $I$. zollingeriana top leaf meal could improve the quality of eggs physically and chemically.
\end{abstract}

Key words: eggs quality, Indigofera zollingeriana, soybean meal, quail

\section{ABSTRAK}

Tujuan penelitian ini adalah untuk mempelajari substitusi protein bungkil kedelai (BKL) dengan protein tepung pucuk Indigofera zollingeriana (TPI) dalam ransum untuk meningkatkan kualitas telur puyuh. Penelitian ini menggunakan rancangan acak lengkap dengan lima perlakuan dan empat ulangan (10 ekor puyuh tiap ulangan). Perlakuan percobaan terdiri atas, $\mathrm{R} 0=$ ransum mengandung $18 \%$ BKL tanpa TPI, R1= 16,2\% BKL dan 2,66\% TPI, R2=14,4\% BKL dan 5,32\% TPI, R3=12,6\% BKL dan $7,98 \%$ TPI, R4=9\% BKL dan 13,3\% TPI. Hasil penelitian menunjukkan bahwa penggunaan 13,3\% TPI (R4) memberikan pengaruh nyata $(P<0,05)$ terhadap konsumsi ransum, meningkatkan bobot telur, warna kuning telur, kolesterol telur, dan menurunkan kadar malondhyaldehide telur. Kesimpulan penelitian ini adalah tepung pucuk I. zollingeriana dapat digunakan sebanyak $13,3 \%$ dalam ransum. Penggunaan tepung pucuk I. zollingeriana dapat meningkatkan kualitas telur secara fisik dan kimia.

Kata kunci: kualitas telur, Indigofera zollingeriana, bungkil kedelai, puyuh

\section{INTRODUCTION}

The quail egg is one of highly nutritious animal protein source that most efficient in providing animal protein sources (Handarini et al., 2008) with an average weight of 6-16 $\mathrm{g}$ (Sezer, 2007). A quail egg composed of $56.83 \%$ of albumin, $34.61 \%$ yolk and $8.56 \%$ eggshell (Kumari et al., 2008). The quail egg was rich in essential amino acids and minerals such as $\mathrm{Ca}, \mathrm{P}$, and Fe (Tolik et al., 2014).

*Corresponding author:

E-mail: $\underline{\text { rmutia.1@gmail.com }}$
In quail formulated ration, source of feed protein is usually derived from meat meal, fish meal and soybean meal at a quite expensive price. In 2013, Indonesia has imported soybean meal up to 3.53 million tons (Ditjen PPHP, 2014). Condition seems to continue to increase in accordance with increasing livestock population. This problem might be overcome by substituting the conventional protein source e.g soybean meal with legume forages. Indigofera zollingeriana is one of the legume tree that has high production and available throughout the year. Total production of I. zollingeriana is $7-10 \mathrm{~kg} /$ ha/crop. The production is based on dry matter of the I. zollingeriana top leaf meal defoliation harvested at 68 days of $1805 \mathrm{~kg} / \mathrm{ha} /$ cutting with an estimated produc- 
tion reached 10830 tons/ha/year (Abdullah \& Suharlina, 2010).

I. zollingeriana has potency as a source of poultry feed ingredient. The leaves of $I$. zollingeriana had a $27.68 \%$ crude protein, $0.08 \%$ tannin, $0.41 \%$ saponin, $1.16 \%$ calcium $(\mathrm{Ca}), 0.26 \%$ phosphorus $(\mathrm{P}), 3.70 \%$ crude fat (CF) and crude fiber (CF) 15.25\% (Abdullah, 2010; Akbarillah et al., 2008). Vitamin content of I. zollingeriana top leaf meal (ILM) were: vitamin D as much as 42.46 $\mathrm{mcg} / 100 \mathrm{~g}$, vitamin K 1.149 ppm, $\alpha$-tocopherol 148.74 $\mathrm{mg} / \mathrm{kg}$ and $\beta$-carotene $507.6 \mathrm{mg} / \mathrm{kg}$ that was not found in soybean meal (Palupi et al., 2014b). Beta carotene is a carotenoid that was also found in ILM for yolk pigmentation. Based on the potency of I. zollingeriana, this research was conducted to study the effect of substitution of soybean meal with I. zollingeriana top leaf meal in the formulated quail ration.

\section{MATERIALS AND METHODS}

\section{Experimental Design, Bird Management, and Experimental Diets}

I. zollingeriana top leaf meal (ILM) was obtained from Bogor Agricultural University Plantations Education and Research in Jonggol, West Java. I. zollingeriana top leaf meal was processed into flour by sundrying for $30 \mathrm{~min}$ and then was ground to become ILM powder. The protein content of the ILM powder was $28.41 \%$. The content of crude protein in I. zollingeriana was $27.68 \%$ or $28.98 \%$ (Palupi et al., $2014 \mathrm{~b}$ ).

This study used nine weeks old laying quail (Cortunix Cortunix Japonica) with an average egg production of $50 \%$. A completely randomized design of five treatments and four replications consisted of 10 birds in each replication was used in this in study. The birds were distributed into 20 units of cages $(60 \times 40 \times 20 \mathrm{~cm})$. The dietary treatments contained five combinations of soybean meal (SBM) and ILM, R0= diets contained of $18 \%$ SBM without ILM, R1 $=16.2 \%$ SBM and $2.66 \%$ ILM, R2 $=14.4 \%$ SBM and 5.32\% ILM, R3 $=12.6 \%$ SBM and $7.98 \%$ ILM, R4=9\% SBM and 13.3\% ILM. Each cage was equipped with a lighting bulb. Drinking water was supplied ad libitum and the feed was given twice, once in the morning and once in the afternoon. Prior to the experiment, the birds were acclimatized to the experimental rations for one week before and the data collection was done for 8 weeks after acclimatization. Rations were formulated according to the standard of nutrient requirements for quail (NRC, 1994), It composed of $20 \%$ crude protein and $2900 \mathrm{Kcal} / \mathrm{kg}$ of metabolizable energy. Composition and nutrient content of the treatments are showed in Table 1.

\section{Variables Measured}

Feed consumption. Feed consumption was measured every week by substracting the amount of rations given with the amount of leftover.

Physical eggs quality. The eggs physical quality analysis began in the second week of observation. Egg collection was carried out for six consecutive weeks. There eggs per experimental replication were sampled randomly once a week. Egg weight (g), eggshell weight (g), yolk weight (g), and albumen weight (g) were measured by using digital scales (Osuka-HWH®, Japan). The thickness of the shell and the height of egg white $(\mathrm{mm})$ were measured by using 150 Digital Caliper of Nankai®, Japan). Haugh unit was measured according to the methods of Buckle et al. (1986), and egg yolk score was determined by comparing standards color of Egg yolk on Roche Yolk Colour Fan (Ovo Color, Aktiengesellscharft BASF, Germany).

Yolk cholesterol. The determination of yolk cholesterol levels was carried out at the end of the observation. One egg from each replication was sampled at random for analysis. Analysis of egg cholesterol was conducted in accordance with the method of Liebermann Burchard (Burke et al., 1974) and the absorbance was read using spectrophotometer reading of Hitachi U-2001, Japan at $500 \mathrm{~nm}$ wavelength $(\lambda)$.

Yolk malondialdehyde (MDA). Malondialdehyde was analyzed by using method of Rice-Evans et al. (1991). MDA measurement was carried out at the end of the study. About one gram of egg yolk, PBS (phosphate buffered saline) with $\mathrm{pH} 4, \mathrm{KCl} 11.4 \mathrm{~g} / \mathrm{L}$, containing cold $\mathrm{KCl}$ with the ratio of 1: 2 was added and then homogenized by using centrifuge at a speed of $10000 \mathrm{rpm}$ for $20 \mathrm{~min}$ at a temperature of $40^{\circ} \mathrm{C}$. $0.5 \mathrm{~mL}$ of supernatant formed was added into a mixture of concentrate $\mathrm{HCl}(2.23 \mathrm{~mL})$ with $15 \mathrm{~g}$ TCA (thricloroacetic), $0.38 \mathrm{~g}$ TBA (thiobarbituric acid) and $100 \mathrm{~mL}$ of distilled water. Homogeneous samples were then stored in the oven with a temperature of $80^{\circ} \mathrm{C}$ for one hour, centrifuged with a speed of $3000 \mathrm{rpm}$ for $15 \mathrm{~min}$ and cooled before absorbance reading. Absorbance was read using spectrofometer Hitachi U-2001, Japan in wave $(\lambda)$ of $523 \mathrm{~nm}$.

\section{Data Analysis}

Data were analyzed by using the Statistical Package for Social Sciences (IBM $® S P S S \AA$ version 21.0). Significantly different means level was determined by one-way analysis of variance (ANOVA). The mean value differences were considered significant at the level of $\mathrm{P}<0.05$, the data were further analyzed by using Duncan multiple range test (Mattjik \& Sumartajaya, 2006)

\section{RESULTS AND DISCUSSION}

\section{Feed Consumption and Physical Quality of the Eggs}

Results of this study indicated that the use of ILM as much as $13.3 \%$ (R4) as the substitution of $50 \%$ protein soybean meal significantly $(\mathrm{P}<0.05)$ increased feed consumption (Table 2). This condition indicated that the diet containing ILM had good palatability. Phytochemical content in the constituent material ration affected the palatability of diets, ILM had a low phytochemical content as much as $0.29 \%$ tannin and $0.036 \%$ saponin (Palupi et al., 2014a). Saponin tolerance 
Table 1. Feed ingredients and nutrient compositions of diets with substitution of protein soybean meal (SBM) by I. zollingeriana top leaf meal (ILM) (\%)

\begin{tabular}{|c|c|c|c|c|c|}
\hline \multirow{2}{*}{ Feed ingredients } & \multicolumn{5}{|c|}{ Treatments } \\
\hline & R0 & R1 & $\mathrm{R} 2$ & $\mathrm{R} 3$ & $\mathrm{R} 4$ \\
\hline Yellow corn & 52.72 & 51.87 & 51.8 & 50.72 & 51.00 \\
\hline Rice bran & 7.66 & 7.71 & 6.91 & 6.98 & 4.89 \\
\hline Soybean meal & 18.00 & 16.2 & 14.4 & 12.60 & 9.00 \\
\hline ILM & 0.00 & 2.66 & 5.32 & 7.98 & 13.30 \\
\hline Fish Meal & 9.50 & 9.50 & 9.50 & 9.50 & 9.50 \\
\hline $\mathrm{CaCo} 3$ & 5.00 & 5.00 & 5.00 & 5.00 & 5.00 \\
\hline Oil & 2.50 & 2.50 & 2.50 & 2.50 & 2.50 \\
\hline Premix & 0.30 & 0.30 & 0.30 & 0.30 & 0.30 \\
\hline DL-Methionine & 0.05 & 0.09 & 0.00 & 0.00 & 0.09 \\
\hline L-Lysine & 0.10 & 0.00 & 0.10 & 0.20 & 0.10 \\
\hline $\mathrm{NaCl}$ (salt) & 0.07 & 0.07 & 0.07 & 0.07 & 0.07 \\
\hline Dicalcium phosphate & 0.10 & 0.10 & 0.10 & 0.15 & 0.25 \\
\hline Corn gluten meal & 4.00 & 4.00 & 4.00 & 4.00 & 4.00 \\
\hline Total & 100.00 & 100.00 & 100.00 & 100.00 & 100.00 \\
\hline Crude protein & 20.55 & 20.49 & 20.39 & 20.32 & 20.10 \\
\hline Crude fat & 5.24 & 5.47 & 5.68 & 5.89 & 6.32 \\
\hline Crude fiber & 2.97 & 3.43 & 3.81 & 4.27 & 4.98 \\
\hline Calsium & 2.59 & 2.58 & 2.58 & 2.56 & 2.60 \\
\hline Phosphor & 0.55 & 0.55 & 0.54 & 0.55 & 0.55 \\
\hline Methionine & 0.48 & 0.45 & 0.46 & 0.45 & 0.51 \\
\hline Lysine & 1.36 & 1.16 & 1.24 & 1.28 & 1.05 \\
\hline Chlorine & 0.14 & 0.14 & 0.14 & 0.14 & 0.13 \\
\hline Sodium & 0.12 & 0.12 & 0.12 & 0.11 & 0.11 \\
\hline Meth + cystine & 0.72 & 0.89 & 0.77 & 0.75 & 0.77 \\
\hline Metabolizable energy (kkal/kg) & 2971.37 & 2953.38 & 2945.23 & 2919.97 & 2908.33 \\
\hline
\end{tabular}

Note: $\mathrm{R} 0=$ diets contained of $18 \%$ soybean meal (SBM) without $I$. zollingeriana top leaf meal (ILM), R1=16.2\% SBM and 2.66\% ILM, R2=14.4\% SBM and $5.32 \%$ ILM, R3 $=12.6 \%$ SBM and $7.98 \%$ ILM, R4= 9\% SBM and $13.3 \%$ of ILM.

Table 2. Feed consumption and physical qualities of eggs produced by quails fed diets with substitution of protein soybean meal (SBM) by I. zollingeriana top leaf meal (ILM)

\begin{tabular}{lccccc}
\hline \multirow{2}{*}{ Variables } & \multicolumn{5}{c}{ Treatments } \\
\cline { 2 - 6 } & \multicolumn{1}{c}{ R0 } & R1 & R2 & R3 & R4 \\
\hline Feed consumption (g/head) & $18.96 \pm 0.97^{\mathrm{b}}$ & $20.44 \pm 0.97^{\mathrm{ab}}$ & $19.47 \pm 1.07^{\mathrm{a}}$ & $20.59 \pm 1.08^{\mathrm{ab}}$ & $21.32 \pm 0.71^{\mathrm{a}}$ \\
Egg weight (g) & $8.83 \pm 0.11^{\mathrm{bc}}$ & $9.05 \pm 0.26^{\mathrm{ab}}$ & $8.73 \pm 0.14^{\mathrm{c}}$ & $8.92 \pm 0.06^{\mathrm{bc}}$ & $9.32 \pm 0.16^{\mathrm{a}}$ \\
Yolk colour & $6.24 \pm 0.91^{\mathrm{c}}$ & $8.14 \pm 0.16^{\mathrm{b}}$ & $8.65 \pm 0.12^{\mathrm{b}}$ & $9.24 \pm 0.59^{\mathrm{a}}$ & $9.46 \pm 0.44^{\mathrm{a}}$ \\
Egg shape & $81.34 \pm 1.32$ & $81.74 \pm 0.40$ & $81.72 \pm 0.47$ & $81.25 \pm 2.81$ & $82.34 \pm 1.17$ \\
Haugh unit & $91.52 \pm 0.44$ & $91.70 \pm 0.94$ & $91.97 \pm 0.26$ & $91.05 \pm 0.71$ & $92.39 \pm 1.75$ \\
Egg shell (\%) & $11.94 \pm 0.68$ & $12.16 \pm 0.35$ & $12.26 \pm 0.35$ & $12.02 \pm 0.46$ & $12.13 \pm 0.12$ \\
Egg yolk (\%) & $31.31 \pm 1.19$ & $31.77 \pm 0.76$ & $31.91 \pm 1.15$ & $33.05 \pm 1.01$ & $33.07 \pm 0.70$ \\
Albumen (\%) & $56.75 \pm 0.80$ & $56.06 \pm 0.50$ & $55.83 \pm 1.24$ & $54.93 \pm 0.84$ & $54.80 \pm 0.67$ \\
\hline
\end{tabular}

Note: Means in the same row with different superscripts differ significantly $(\mathrm{P}<0.05)$. R0= diets contained of $18 \%$ soybean meal (SBM) without $I$. zollingeriana top leaf meal (ILM), R1= 16.2\% SBM and 2.66\% ILM, R2= 14.4\% SBM and 5.32\% ILM, R3=12.6\% SBM and 7.98\% ILM, R4=9\% SBM and $13.3 \%$ of ILM.

in poultry rations was $0.37 \%$ and $0.5 \%$ tannins according to Kumar (2005) and Leeson \& Summer (2005), respectively. Feed consumption was affected by environmental temperature, also the quality and quantity of ration (Leeson \& Summer, 2005).

\section{Physical Quality of the Eggs}

Substitution of soybean meal with 13.3\% (R4) ILM significantly $(\mathrm{P}<0.05)$ increased egg weight and score of yolk colour (Table 2). The average eggs weight in this study ranged from 8.73 to $9.32 \mathrm{~g}$ and the results obtained were still at the normal range of 6-16 g (Sezer, 
Table 3. Chemical quality of eggs (MDA and cholesterol) produced by quails fed diets with substitution of protein soybean meal (SBM) by I. zollingeriana top leaf meal (ILM)

\begin{tabular}{lcccrr}
\hline \multirow{2}{*}{ Variables } & \multicolumn{5}{c}{ Treatments } \\
\cline { 2 - 6 } & R0 & R1 & R2 & R3 & R4 \\
\hline MDA $(\mu \mathrm{g} / \mathrm{g})$ & $5.40 \pm 0.51^{\mathrm{a}}$ & $5.31 \pm 0.73^{\mathrm{a}}$ & $3.09 \pm 0.69^{\mathrm{b}}$ & $3.11 \pm 0.80^{\mathrm{b}}$ & $3.02 \pm 0.46^{\mathrm{b}}$ \\
Cholesterol $(\mathrm{mg} / \mathrm{g})$ & $6.67 \pm 0.95^{\mathrm{b}}$ & $7.08 \pm 1.08^{\mathrm{b}}$ & $7.85 \pm 1.15^{\mathrm{b}}$ & $12.05 \pm 1.39^{\mathrm{a}}$ & $10.42 \pm 0.78^{\mathrm{a}}$ \\
\hline
\end{tabular}

Note: Means in the same row with different superscripts differ significantly $(\mathrm{P}<0.05)$. R0= diets contained of $18 \%$ soybean meal (SBM) without $I$. zollingeriana top leaf meal (ILM), R1= 16.2\% SBM and 2.66\% ILM, R2=14.4\% SBM and 5.32\% ILM, R3= $12.6 \%$ SBM and $7.98 \%$ ILM, R4= 9\% SBM and $13.3 \%$ of ILM.

2007). Egg size is influenced by the content of protein as amino acids. I. zollingeriana top leaf meal has amino acid score as well as soybean meal (Palupi et al., 2014b). According to Grindstaff et al. (2005), the process of egg formation is influenced by the nutrients in the diets consumed by poultry.

In general, actually the addition of carotenoids in the feed increased score of yolk colour (McGraw, 2006; Amo et al., 2013; Jiang et al., 2013; Palupi et al., 2014a). In term of yolk color, substitution of soybean meal with ILM by $2.66 \%-13.3 \%$ in the diets improved the egg quality. The increase in score of yolk color due to the addition of ILM indicates that $\beta$-carotene contained in ILM is possibly deposited into the yolk. Deposition of beta-carotene in the yolk depended on the efficiency of transferring carotene from the intestine into the ovum (Hammershoj et al., 2010). The content of carotenoids and xanthophyll in the ration was contributed by ILM and greatly affected the colour of egg yolk (Akbarillah et al., 2010). Most of $\beta$-carotene was also an antioxidant that would be converted into an anti-free radical (Loetscher et al., 2013).

However, the addition of ILM in quail's ration did not affect eggs shape, haugh unit, eggshell or albumen (Table 2). The egg shape is the ratio between the width to the length of the whole eggs. In this study, eggs produced tended to be rounded as was indicated by an increase in egg shape value. An ideal shape value of quail's egg was 79.90 (Kumari et al., 2008). A slight increase but not statistically significant of haugh units in R4 was probably influenced by the contribution of dietary protein and amino acid. This was supported by the content of amino acid balance in ILM that was close to soybean meal amino acid balance score (Palupi et al., 2014 b). Albumen height was influenced by the viscosity of albumen (Zita et al., 2012). The high value of haugh units would describe the quality of the eggs (Alkan et al., 2010). In this study the unit ranging from 91.05 to 92.39 was considerably good. According to Zita et al. (2013) haugh units was influenced by the factors of age, 9-17 weeks old quails have haugh units of eggs 90.1390.50. The percentage of egg shell in the study showed a slight increase, compared with the control diets. The balance of calcium $(\mathrm{Ca})$ and phosphorus $(\mathrm{P})$ in the ration played an important role in the formation of egg shell. According to the NRC (1994) laying quail ration needed $2.5 \% \mathrm{Ca}$ and $0.55 \% \mathrm{P}$. The balance of the two minerals was very important because $\mathrm{Ca}$ and $\mathrm{P}$ also would affect egg production (Amoah et al., 2012).

\section{Chemical Quality of the Eggs}

Malondialdehyde (MDA) is one indicator to see antioxidant activity (Chen et al., 2009). Increased free radicals would stimulate the process of lipid peroxidation and oxidative stress, which could be measured by analyzing the content of MDA (Valko et al., 2006). Substitution of soybean meal with 5.32\%-13.3\% (R1R4) ILM in quail diets significantly decreased $(\mathrm{P}<0.05)$ the MDA and increased yolk cholesterol (Table 3). The lower content of MDA in egg yolk in R4 was probably due to the role of antioxidants in the ILM which reduced lipid peroxidation. Antioxidants were actually stable which could reduce the levels of MDA in the yolk as well as in serum and liver (Sahin et al., 2008; Ni et al., 2012; Kurtoglu et al., 2008). Beta carotene in ILM acted as an antioxidant so did the isoflavone. The process of lipid peroxidation was triggered by the separation of hydrogen. The presence antioxidants donates a hydrogen group to ILM substitution (Wang et al., 2005).

Quail's eggs had a high concentration of polyunsaturated fatty acids with cholesterol content of only $7.78 \mathrm{mg} / \mathrm{g}$ (Mennicken et al., 2005; Kazmierska et al., 2005). Increased yolk cholesterol with the increase ILM substitution was influenced by the role of $\beta$-carotene as an antioxidant for anti-free radical as to minimize lipid peroxidation process without interfering the formation of cholesterol. Giving antioxidants and $\beta$-carotene could reduce the levels of SGOT (Serum transaminases Glutamix Oxaloatic) and SGPT (Serum Glutamic Pyruvic Transaminase), showing the occurrence of lipid peroxidation (Jaya, 2013). Beta carotene supplementation in the diet would affect the activation of lipid peroxidation and antioxidant enzyme that protected cholesterol from damage (Shih et al., 2008). This condition would benefit the quail, because cholesterol is needed in the process of embryos development to produce DOQ (day old quail). Egg yolk is rich in lipids, vitamins A, E and $\beta$-carotene which will be transferred to a membrane bag by the phagocytosis to form lipoprotein particles that are released into the circulation of embryos that supports the growth and development of the embryo (McGraw, 2006).

\section{CONCLUSION}

Indigofera zollingeriana top leaf meal (ILM) could be used in the diet of laying quail (Cortunix Cortunix Japonica) up to $13.3 \%$ as substitution of $50 \%$ protein in 
soybean meal. Supplementation of ILM increased feed consumption, egg weight, egg yolk colour, egg yolk cholesterol and reduced levels of malondialdehyde in the quail's eggs.

\section{REFERENCES}

Abdullah, L. 2010. Herbage production and quality of shrubh Indigofera sp treated by different concentration of foliar fertilizer. Med. Pet. 33:169-175. http://dx.doi.org/10.5398/ medpet.2010.33.3.169

Abdullah, L. \& Suharlina. 2010. Herbage yeld and quality of two vegetative parts of indigofera at different time of first regrowth defoliation. Med. Pet. 33:44-49.

Akbarillah, T., Kususiyah, \& Hidayat. 2010. The effect of fresh Indigofera leaves utilization as feed supplementation on egg production and its yolk color of ducks. JSPI. 5:27-33.

Akbarillah, T., Kususiyah, D. Kaharuddin, \& Hidayat. 2008. Kajian tepung daun indigofera sebagai suplemen pakan terhadap produksi dan kualitas telur puyuh. JSPI 3:20-23.

Alkan, S. K., A. Karabag, T. Galic, M. S. Karsli, \& Balcioglu. 2010. Effects of selection for body weight and egg production on egg quality traits in Japanese quails (Coturnix coturnix japonica) of different lines and relationships between these traits. Kafkas Univ. Vet. Fak. Derg. 16: 239-244.

Amo, M., J. L. P. Saerang, M. Najoan, \& J. Keintjem. 2013. Pengaruh penambahan tepung kunyit (Curcuma domestica val) dalam ransum terhadap kualitas telur puyuh (Coturnixcoturnix japonica). J. Zootek. 33:0851-2626.

Amoah, J. K., E. A. Martin, A. J. Barroga, E. P. Garillo, \& I. Domigo. 2012. Calcium and phosphorus requirements of Japanese quail layers. J. App. Biosci. 54: 3892-3900.

Buckle, K. A., R. Edward, G. H. Fleet, \& M. Wooton. 1986. Ilmu Pangan. Terjemahan: H. Purnomo \& Adiono. UI Pr, Jakarta.

Burke, R. W., B. I. Diamondstone, R. A. Velapoldi, \& O. Menis. 1974. Mechanisms of the Liebermann-Burchard and zak color reactions for cholesterol. Clin. Chem. 20:94-801.

Chen, P., A. Q Wang. \& A. S. Shan. 2009. Effects of Ligustrum lucidum fruits on growth performance, antioxidation and meat quality in arbor acres broilers. Asian Australas. J. Anim. Sci. 22:700-705. http://dx.doi.org/10.5713/ ajas.2009.80537

Ditjen PPHP. 2014. Statistik Ekspor Impor Komoditas Pertanian 2001-2013. Jurnal Statistik Ekspor Impor Komoditas Pertanian. ISSN: 2337-9578. Hlm. 1-33.

Grindstaff, J. L., G. E. Demas, \& E. D. Ketterson. 2005. Diet quality affects egg size and number but does not reduce maternal antibody transmission in Japanese quail Coturnix japonica. J. Anim. Ecol. 74:1051-1058. http://dx.doi. org/10.1111/j.1365-2656.2005.01002.x

Hammershoj, M., U. Kidmose, \& S. Steenfeldt. 2010. Deposition of carotenoids in egg yolk by short-term supplement of coloured carrot (Daucus carota) varieties as forage material for egg-laying hens. J. Sci. Food. Agric. 90:1163-1171. http://dx.doi.org/10.1002/jsfa.3937

Handarini, R., E. Saleh, \& B. Togatorop. 2008. Produksi burung puyuh yang diberi ransum dengan penambahan tepung umbut sawit fermentasi. Agri. Pet. 4:107-110.

Jaya, E. F. P. 2013. The utilization of antioxidant and betacarotene of purple sweet potato in making nonalcoholic drink. Media Gizi Masyarakat Indonesia 2:54-57.

Jiang, W., L. Zhang, \& A. Shan. 2013. The effect of vitamin E on laying performance and egg quality in laying hens fed corn dried distillers grains with soluble. Poultry Sci. 92:2956-2964. http://dx.doi.org/10.3382/ps.2013-03228

Kazmierska, M., B. Jarosz, M. Korzeniowska1, T. Trziszka1, \& Z. Dobrzanski. 2005. Comparative analysis of fatty acid profile and cholesterol content of egg yolks of different bird species. Pol. J. Food. Nutr. Sci. 14:69-73.

Kumar, V., A. V. Elangovan, \& A. B. Mandal. 2005. Utilization of reconstituted high-tannin sorghum in the diets of broiler chicken. J. Anim. Sci. 4: 538-544.

Kumari, P. B., G. B. Ramesh, P. M. Gnana, \& R. A. Rajasekhar RA. 2008. A study on eggs quality traits in Japaniese quail (Cortunix Coertunix Japonica) Tamilnadu. J. Vet. Sci. 4:227231.

Kurtoglu, F., V. Kurtoglu, \& A. Sivrikaya. 2008. Effects of vitamin E supplementation on antioxidation and lipid profiles of rats on diets supplemented with cholesterol and olive oil. Asian Australas. J. Anim. Sci. 21:883-889. http://dx.doi. org/10.5713/ajas.2008.70613

Leeson, S., \& J. D. Summers. 2005. Comercial Poultry Nutrition. $3^{\text {rd }}$ Ed. Nottingham University Press, Nottingham.

Loetscher, Y., M. Kreuzer, \& R. E. Messikommer. 2013. Utility of nettle (Urtica dioica) in layer diets as a natural yellow colorant for egg yolk. Anim. Feed. Sci. Technol. 186:158168. http://dx.doi.org/10.1016/j.anifeedsci.2013.10.006

Mattjik, A. A. \& I. M. Sumertajaya. 2006. Perancangan percobaan dengan aplilkasi SAS dan MINITAB. Jilid I. Edisi ke2. Institut Pertanian Bogor (IPB)-Press, Bogor.

McGraw, K. J. 2006. Dietary carotenoids mediate a trade-off between egg quantity and quality in Japanese quail. Ethol. Ecol. Evol. 18: 247-256. http://dx.doi.org/10.1080/08927014 .2006 .9522712

Mennicken, L., S. Ponsuksili, E. Tholen, N. T. K. Khang, K. Steier, J. Petersen, K. Schellander, \& K. Wimmers. 2005. Divergent selection for $\omega 3: \omega 6$ polyunsaturated fatty acid ratio in quail eggs. Arch. Tierz. Dummerstorf. 48:527-534.

[NRC] National Research Council. 1994. Nutrient Requirement of Poultry. Revised Edition. National Academy Press, Washington DC.

Ni, Y. D., J. Wu, H.Y. Tong, Y.B. Huang, L.Z. Lu, R. Grossmann, \& R.Q. Zhao. 2012. Effect of dietary daidzein supplementation on egg laying rate was associated with the change of hepatic VTG-II mRNA expression and higher antioxidant activities during the post-peak egg laying period of broiler breeders. Anim. Feed Sci. Technol. 177:116-123. http:// dx.doi.org/10.1016/j.anifeedsci.2012.08.001

Palupi, R., L. Abdullah, D. A. Astuti, \& Sumiati. 2014a. High antioxidant egg production through substitution of soybean meal by Indigofera sp., Top leaf meal in laying hen diets. Inter. J. Poultry Sci. 13:198-203. http://dx.doi.org/10.3923/ ijps.2014.198.203

Palupi, R., L. Abdullah, D. A. Astuti, \& Sumiati. 2014b. Potential and utilization of Indigofera $s p$ shoot leaf meal as soybean meal substitution in laying hen diets. JITV. 19:210219.

Rice-Evans, C. A., A. T. Diplock, \& M. C. Symons. 1991. Techniques in free radical research. Laboratory Techniques in Biochemistry and Molecular Biology 22: 146-202.

Sahin, N., F. Akdemir, C. Orhan, O. Kucuk, A. Hayirli, \& K. Sahin. 2008. Lycopene-enriched quail egg as functional food for humans. Food. Res. Int. 41:295-300. http://dx.doi. org/10.1016/j.foodres.2007.12.006

Sezer, M. 2007. Heritability of exterior eggs quality traits in Japanese quail. J. Appl. Biol. Sci.1:37-40.

Shih, K. C., J. H. Chang., S. H. Yang, T. W. Chou, \& H. H. Cheng. 2008. $\beta$-caroten and canthaxanthin alter the prooxidation and antioxidant balance in rats fed a high-cholesterol and high-fat diets. Brit. J. Nutr. 99:59-66. http:// dx.doi.org/10.1017/S0007114507781497

Statistical Package for Social Sciences. 2012. IBM SPSS 21.0 for windows (SPSS Inc., United States).

Tolik, D., E. Polawska, A. Charuta, S. Nowaczewski, \& R. Cooper. 2014. Characteristics of egg parts, chemical composition and nutritive value of Japanese quail eggs. Folia 
Biologica (Krakow) 62: 287-292. http://dx.doi.org/10.3409/ fb62 4.287

Valko, M., C. J. Rhodes, J. Moncola, M. Izakovic, \& M. Mazur. 2006. Free radicals, metals and antioxidants in oxidative stress-induced cancer. Chemico Biological Interactions 160: 1-40. http://dx.doi.org/10.1016/j.cbi.2005.12.009

Wang, S. H., Y. Z. Wang, K. Y. Zhang, J. H. Shen, H. Q. Zhou, \& X. Y. Qiu. 2005. Effect of superoxide dismutase and malondialdehyde metabolic changes on carcinogenesis of gastric carcinoma. World J. Gastroenterol. 11:4305-4310.
Zita, L., Z. Ledvinda, E. Tumova, \& L. Klesalova. 2013. The effect of the age of Japanese quails on certain egg quality traits and their relationships. Vet. Arhiv. 83:223-232.

Zita, L., Z. Ledvinda, E. Tumova, \& L. Klesalova. 2012. Technological quality of eggs in relation to the age of laying hens and Japanese quails. Soc. Bras. Zootec.41:2079-2084. http:// dx.doi.org/10.1590/S1516-35982012000900016 